\title{
MENGENAL SOSOK MAHMUD YUNUS DAN PEMIKIRANNYA TENTANG PENDIDIKAN ISLAM
}

\author{
Edi Iskandar
}

Sekolah Tinggi Agama Islam Al-Azhar Pekanbaru Riau Indonesia

Email: edi2012iskandar@gmail.com

\begin{abstract}
This paper wants to elevate the figure of Mahmud Yunus and his thoughts on Islamic education. For that, at least there are some things that need to be presented, including biography and educational background, then put forward his thoughts on Islamic education. His thoughts on Islamic education are related to the goals of Islamic education, Islamic education curriculum, the institutions of Islamic education, methods of learning in Islamic education, as well as moral and ethical of educators. Mahmud Yunus's point of view about Islamic education, although the thought has existed for a long time but it still exists and is relevant in today's time, for the advancement and development of the Islamic educational institutions of the archipelago.
\end{abstract}

Keywords: Islamic education, goals, curriculum, institutions, methods of learning, moral and ethical of educators.

\section{A. Pendahuluan}

Pada saat ini ilmu pendidikan Islam telah diakui sebagai salah satu bidang studi dan telah menarik minat kalangan pelajar dan mahasiswa untuk mengkajinya lebih mendalam. Namun, sebagai sebuah bidang studi baru terlihat kurang begitu berkembang, dibandingkan dengan bidang-bidang studi Islam lainnya. Buku-buku dan bahan-bahan bacaan lainnya yang berkenaan dengan pendidikan Islam dan tokoh-tokoh pendidikan Islam masih sangat kurang. Untuk itu pada tulisan kali ini penulis ingin mengangkat seorang tokoh nusantara yakni Mahmud Yunus, yang mana beliau adalah seorang praktisi dan pemikir dalam dunia pendidikan, terutama pendidikan Islam.Tulisan ini dibagi dalam dua tulisan, pada bagian pertama ini akan diketengahkan sejarah hidup Mahmud Yunus, latar belakang pemikirannya, masa belajar, kondisi sosial politik di zamannya, mobilitas, peranan dan Karya-karya Mahmud Yunus, serta berbagai penghargaan yang diberikan pemerintah Indonesia atas karya dan pengabdiannya. 


\section{B. Biografi dan Latar Belakang Pendidikan}

Riwayat hidup Mahmud Yunus dapat dibagi atas delapan fase (periodesasi), di antaranya:

1. Dari tahun 1906-1909 (masa mengaji al-Qur`an dan Sekolah Desa)

2. Dari tahun 1910-1916 (masa belajar di madrasah)

3. Dari tahun 1917-1923 (masa mengajar di madrasah dan pergi haji ke tanah suci)

4. Dari tahun 1924-1930 (masa belajar di Kairo Mesir)

5. Dari tahun 1931-1946 (masa mengajar di Indonesia)

6. Dari tahun 1947-1956 (masa bertugas di Departemen Agama) merangkap dosen.

7. Dari tahun 1957-1970 (masa jadi rektor pada Perguruan Tinggi Islam-pensiun)

8. Usaha dan kegiatan setelah pensiun.

Mahmud Yunus dilahirkan di sebuah desa yang bernama Sungayang Batu Sangkar Kabupaten Tanah Datar Sumatera Barat. Pada hari Sabtu 30 Ramadhan 1316 H bertepatan 10 Februari 1899 M. ${ }^{1}$ Dia dibesarkan di tengah keluarga yang alim dan taat menjalankan ajaran Islam. Ayahnya bernama Yunus bin Incek bekas pelajar Surau (Pesantren). Ia diangkat menjadi imam menurut sepanjang adat dalam negeri. Yunus bin Incak dikenal seorang yang sangat familiar, jujur, dan berhati mulia. Ibunya bernama Hafsah binti Imam Sami'un. Imam Sami'un adalah putra Doyan M. Ali gelar Engku Kolok, ulama besar di Sungayang. Ibu Mahmud Yunus belum bisa tulis baca, karena pada masa itu pemerintah penjajah belum mendirikan sekolah di desa. Namun ibu Mahmud Yunus mempunyai keahlian bertenun, ia ahli menenun kain yang dihiasi dengan benang emas, yaitu kain kebudayaan asli Minangkabau yang hanya dipakai dalam upacara adat istiadat yang berlaku dalam negeri. Sebelum usia mumayyiz, ayahnya Yunus telah menceraikan ibunya Hafsah, dan Mahmud Yunus lebih banyak diasuh oleh ibunya.

Mahmud Yunus di waktu kecil dikenal sangat kuat hafalannya. Jika ia mendengarkan suatu cerita maka ia dapat mengulangi cerita tersebut secara utuh, dari awal sampai akhir. Pada tahun 1906 sewaktunya berumur lebih kurang 7 tahun, sudah mulai mengaji al-Qur`an di surau kakeknya M. Thahir bin M. Ali gelar Engku Gadang. Mahmud Yunus belajar bersama anak perempuan kakeknya bernama Jamah. Mahmud Yunus belajar dari dasar mengenal huruf-huruf al-Qur`an, ia sangat tekun belajar di 1982), h. 5

${ }^{1}$ Mahmud Yunus, Riwayat Hidup Prof. Dr. H. Mahmud Yunus, (Jakarta: Hidakarya Agung, 
malam hari dan selesai melaksanakan shalat subuh, pada siang harinya ia pun ikut bermain dengan teman-teman seusianya. Setelah Mahmud Yunus menamatkan pelajaran al-Qur`an ia dipercaya sebagai guru bantu di surau tersebut, di samping itu Mahmud Yunus juga mulai mempelajari ilmu sharaf. ${ }^{2}$

Mahmud Yunus diberikan pemahaman oleh kakeknya sekaligus sebagai guru mengajinya bahwa pelajaran yang sangat penting dipelajari adalah membaca dan memahami al-Qur`an serta mempelajari cara shalat secara sempurna, dan bagaimana tuntunan melaksanakan ibadah puasa. Pada masa itu orang kampung masih percaya kepada khurafat dan dongeng-dongeng. Misalnya hari Rabu yang akhir di bulan Safar dikatakan hari yang naas. ${ }^{3}$

\section{Pemikiran tentang Pendidikan Islam}

\section{Tujuan Pendidikan Islam}

Tujuan pendidikan Islam menurut Mahmud Yunus terlihat pada gagasannya yang menghendaki agar lulusan pendidikan Islam tidak kalah dengan lulusan pendidikan yang belajar di sekolah-sekolah yang sudah maju ${ }^{4}$ bahkan lulusan pendidikan Islam tersebut mutunya lebih baik dari lulusan sekolah-sekolah Belanda. Yakni, lulusan pendidikan Islam yang memiliki pengetahuan, keterampilan, dan pengalaman dalam bidang ilmu-ilmu umum, juga memiliki wawasan dan kepribadian Islami yang tangguh. Dengan cara demikian para peserta didik dapat meraih dua kebahagiaan secara berimbang, yaitu kebahagiaan dunia dan akhirat.

Selanjutnya Mahmud Yunus merumuskan tujuan pokok pendidikan Islam ke dalam beberapa hal:

a. Untuk mencerdaskan perseorangan.

${ }^{2}$ Ibid., h. 6-7

${ }^{3}$ Merupakan kepercayaan masyarakat kampung yang sudah mendarah daging, mereka percaya bala dan bencana akan turun ke kota-kota, sebab itu dianjurkan supaya orang pergi keluar kota menghindari bahaya. Kalau tidak keluar kota hendaklah diminum tangkalnya, yaitu: ditulis do'a tolak bala di atas piring dengan tinta, kemudian dibasuh dengan air yang bersih, lalu diminum bersama-sama, Insya Allah terhindar dari bala, Mahmud Yunus pun melakukan hal yang demikian. Ada juga yang menuliskan ayat-ayat al-Qur'an di daun kelapa untuk tangkal pianggang di tengah sawah.

${ }^{4}$ Sebagaimana diketahui bahwa pada masa tersebut tahun 1931 ketika Mahmud Yunus berusaha memperbarui madrasah yang pernah dipimpinnya di Sungayang pada tahun 1918 menjadi Al-Jami'ah alIslamiyah, pada masa itu telah berdiri sekolah-sekolah modern produk Belanda seperti HIK, HIS, dan Mulo. Di sekolah modern tersebut siswa dapat belajar berbagai macam ilmu pengetahuan dengan bahasa pengantar (voertaal) bahasa Belanda dengan metoda langsung. Baca Mahmud Yunus: Riwayat ..., h. 46 
b. Untuk kecakapan mengerjakan pekerjaan. ${ }^{5}$

c. Untuk menyiapkan anak-anak didik, supaya di waktu dewasa kelak mereka cakap melakukan pekerjaan dunia dan amalan akhirat, sehingga tercapai kebahagiaan hidup di dunia dan akhirat. ${ }^{6}$

Perumusan tujuan pendidikan Mahmud Yunus ini terlihat ringkas dan pendek, tetapi isinya dalam dan sangat luas. Supaya anak-anak cakap melaksanakan pekerjaan dunia, mereka harus dididik untuk mengerjakan salah satu bidang kehidupan seperti bertani, berdagang, berternak, bertukang, menjadi guru, dan sebagainya menurut bakat bawaan yang dimiliki seorang anak. Sebaliknya supaya anak cakap melaksanakan amalan akhirat mereka harus dididik, supaya mempunyai keimanan yang kuat, teguh, dan beramal saleh. Untuk itu mereka harus diajarkan keimanan, akhlak, ibadat, dan menyampaikan isi al-Qur`an yang berhubungan dengan yang wajib dikerjakan dan yang haram mesti ditinggalkan. Untuk melahirkan anak-anak seperti itu maka anak harus dibekali ilmu pengetahuan yang berhubungan dengan pekerjaan dunia dan ilmu pengetahuan tentanga amalan akhirat. ${ }^{7}$

Dalam hal mementingkan keilmiahan perseorangan sehingga menuntut seseorang supaya menguasai berbagai ilmu pengetahuan, dan yang kedua mementingkan segi pekerjaan kemasyarakatan dibuktikan dengan amal perbuatan. Kedua-dua tujuan ini mengakui, bahwa ilmu itu harus disertai dengan perbuatan. Namun mereka berbeda pada penafsiran, manakah yang lebih utama dan yang lebih penting di antara ilmu atau perbuatan. Yang pertama mengatakan ilmu lebih penting, dan yang kedua mengatakan perbuatanlah yang lebih penting. Mahmud Yunus menyimpulkan, bahwa golongan yang pertama lebih cenderung kepada aliran kerohanian (spiritualisme) ${ }^{8}$ dan golongan kedua lebih lebih cenderung kepada kebendaan (materialisme). ${ }^{9}$

\footnotetext{
5 Mahmud Yunus, Pokok-pokok Pendidikan dan Pengajaran, (Jakarta: PT. Hidakarya Agung, 1978), cet. ke-2, h. 6

${ }^{6}$ Ibid., h. 10

${ }^{7}$ Ibid.

${ }^{8}$ Aliran kerohanian (spiritualisme) berpendapat bahwa hidup di dunia ini hampa dan kosong dari kebaikan dan kemanfaatan yang hakiki, sebab itu harus dijauhkan diri dari sifat loba dan tamak terhadap kebendaan dunia. Mereka hanya menilai dan menghargai kecerdasan semata-mata, bukan karena hendak mendapat kemanfaatan atau untuk menghindarkan kemelaratan, tetapi hanya kecerdasan saja. Lihat: ibid., h. 7

9 Aliran kebendaan (materialisme) berpendapat bahwa dunia dan segala isinya adalah tujuan hidup manusia. Sebab itu harus diambil kemanfaatan duniawi sebanyak-banyaknya dan jangan dibuang kesempatan. Hidup di dunia bukanlah wasilah untuk kehidupan akhirat (tidak ada hubungan hidup di dunia dengan akhirat). Kelompok ini menilai suatu pekerjaan dan usaha yang tidak ada manfaat dan faedahnya bagi kehidupan dunia maka jangan dikerjakan. Lihat: ibid.
} 
Selanjutnya Mahmud Yunus menilai pendapat ulama tradisional yang mengatakan bahwa tujuan pendidikan Islam hanyalah untuk beribadah dan sekedar untuk mempelajari dan mendalami agama Islam, sebagai pendapat yang sempit, kurang, dan tidak sempurna. Karena menurutnya, beribadah itu merupakan salah satu perintah Allah. Sedangkan pekerjaan duniawi yang menguatkan pengabdian kepada Allah merupakan ajaran Islam. Dengan demikian, berarti pekerjaan duniawi termasuk bagian tujuan pendidikan Islam. ${ }^{10}$

Selain itu, Mahmud Yunus juga menilai pendapat yang mengatakan bahwa tujuan pendidikan Islam adalah mempelajari dan mengetahui ilmu-ilmu agama Islam serta mengamalkannya, seperti ilmu tauhid, fiqh, tafsir, hadis dan sebagainya. Tujuan ini banyak dilaksanakan di madrasah-madrasah seluruh dunia Islam selama beratusratus tahun lamanya, sesudah mundurnya umat Islam. ${ }^{11}$ Pada masa di mana ilmu-ilmu yang berhubungan dengan duniawi tidak diajarkan sama sekali, bahkan ada ulama yang mengharamkan mengajarkan ilmu-ilmu umum. Tujuan yang demikian menyebabkan umat Islam menjadi lemah dalam kehidupan di dunia dan tidak sanggup mempertahankan kemerdekaannya, akhirnya umat Islam dijajah oleh bangsa yang kuat, sebagaimana telah terjadi selama beratus-ratus tahun. ${ }^{12}$ Bahkan kejayaan yang pernah diraih umat Islam yang merupakan lambang kejayaan umat Islam semuanya dikuasai dan tunduk pada kekuasaan Barat, seperti halnya kota Bagdad dan Cordova. ${ }^{13}$

${ }^{10}$ Mahmud Yunus dan Kasin Bakri, al-Tarbiyah wa al-Ta'lim, Jilid 1 a, (Gontor: Pondok Pesantren Darussalam Gontor, 1986), h. 13

11 Fazlur Rahman, dalam bukunya Islam, menjelaskan tentang gejala-gejala kemunduran/kemacetan intelektual Islam: "Penutupan pintu ijtihad (pemikiran yang orisinil dan bebas) selama abad ke 4 H/10 M dan 5 H/11 M telah membawa kepada kemacetan umum dalam ilmu hukum dan intelektual. Ilmu-ilmu yang berhubungan dengan teologi dan pemikiran keagamaan mengalami kemunduran yang amat sangat, dikucilkan. Ilmu filsafat juga dikucilkan dari kurikulum pendidikan yang diganti dengan pemikiran keagamaan yang berbau sufisme. Lihat: Fazlur Rahman, Islam, (terj) (Bandung: Pustaka, 1984), h. 270. Kehancuran total yang dialami oleh kota Bagdad dan Granada sebagai pusat-pusat pendidikan dan kebudayaan Islam, menandai runtuhnya sendi-sendi pendidikan dan kebudayaan Islam. Musnahnya lembaga-lembaga pendidikan dan semua buku ilmu pengetahuan dari kedua pusat pendidikan di bagian Timur dan Barat dunia Islam tersebut, menyebabkan kemunduran total umat Islam seluruh dunia terutama di bidang intelektual dan filsafat sementara untuk kehidupan sufisme berkembang dengan pesat. Lihat: Zuhairini, Sejarah Pendidikan Islam, (Jakarta: Bumi Aksara, 2008), Cet. ke-9, h.111-112

${ }^{12}$ Mahmud Yunus, Pokok-pokok ..., h. 10

${ }^{13}$ Hancurnya Kota Bagdad di belahan dunia Timur (1258 M.) disebabkan oleh 2 faktor (intern dan ekstern), pertama, faktor intern: (a) adanya persaingan tidak sehat antara beberapa bangsa yang terhimpun dalam daulah Abbasiyah terutama Arab, Persia, dan Turki; (b) adanya konflik aliran pemikiran dalam Islam yang menimbulkan konflik berdarah; (c) munculnya dinasti-dinasti kecil yang memerdekakan diri dari kekuasaan Bagdad; (d) kemerosotan ekonomi akibat konflik politik yang berkepanjangan. Adapun faktor ekstern: (a) Perang Salib yang terjadi beberapa kali; (b) ekspansi yang dilakukan tentara Mongol di bawah pimpinan Hulagu Khan, inilah secara langsung yang menyebabkan kehancuran total daulah Abbasiyah dan jatuhnya Bagdad. Sedangkan kehancuran kota Cordova pusat 
Berdasarkan pemikiran di atas, Mahmud Yunus sampai pada kesimpulan bahwa tujuan pendidikan Islam adalah menyiapkan anak-anak didik agar pada waktu dewasa kelak mereka sanggup dan cakap melakukan pekerjaan dunia dan amalan akhirat, sehingga tercipta kebahagiaan bersama dunia dan akhirat. Inspirasi pemikiran ini agaknya dia landaskan pada ayat al-Qur`an. Firman Allah SWT.:

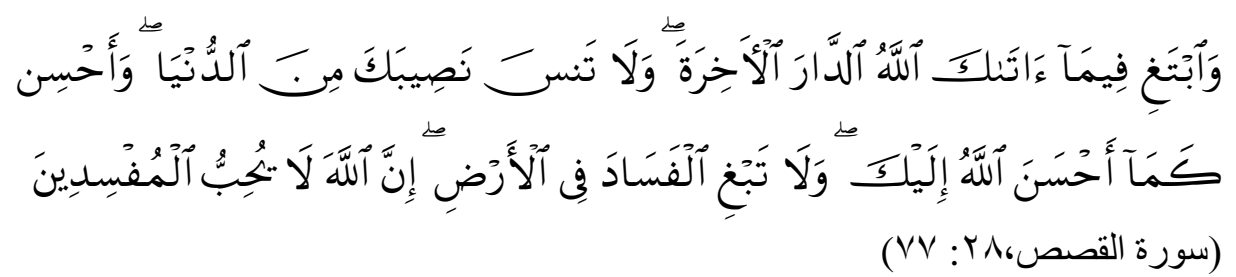

"Dan carilah pada apa yang telah dianugerahkan Allah kepadamu (kebahagiaan) negeri akhirat, dan janganlah kamu melupakan bahagianmu dari (kenikmatan) duniawi dan berbuat baiklah (kepada orang lain) sebagaimana Allah telah berbuat baik, kepadamu, dan janganlah kamu berbuat kerusakan di (muka) bumi. Sesungguhnya Allah tidak menyukai orang-orang yang berbuat kerusakan." (Q.S. AlQashash, 28: 77).

Untuk menjadikan anak cakap melaksanakan amalan akhirat, harus diajarkan kepada mereka keimanan, akhlak, ibadah, dan isi al-Qur`an yang berhubungan dengan yang wajib dikerjakan dan yang haram harus ditinggalkan. Selanjutnya agar anak didik cakap melaksanakan pekerjaan dunia, mereka harus dididik mengerjakan salah satu dari macam-macam profesi, seperti bertani, berternak, berdagang, bertukang, menjadi guru, buruh dan sebagainya sesuai bakat dan pembawaan masing-masing anak didik. ${ }^{14}$ Mahmud Yunus juga melandaskan perumusan tujuan pendidikan pada ayat al-Qur`an. Firman Allah SWT.:

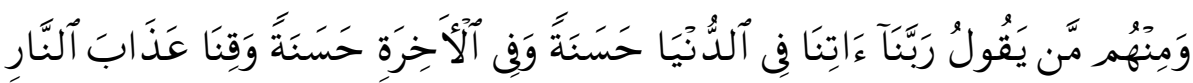

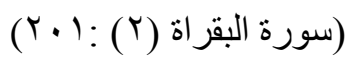

\footnotetext{
Islam di Barat, disebabkan oleh: (a) tidak jelasnya sistem peralihan kekuasaan yang menyebabkan munculnya perebutan kekuasaan di antara ahli waris; (b) lemahnya figur dan karismatik yang dimiliki khalifah, semakin menguat semenjak peninggalan khalifah al-Hakam II; (c) perselisihan di kalangan umat Islam itu sendiri; (d) konflik horizontal Islam dan Kristen; dan (e) munculnya Muluk al-Thawaif (raja-raja kecil). Pada akhirnya datang serangan Kristen yang sudah menyatu dan berhasil melumpuhkan kekuasaan Islam. Baca Syamsul Nizar, Sejarah Pendidikan Islam; Menelusuri Jejak Sejarah Pendidikan Era Rasulullah Sampai Indonesia, (Jakarta: Prenada Media Group, 2007), h. 172-176

${ }^{14}$ Mahmud Yunus, Pokok-pokok ...
} 
"Dan di antara mereka ada orang yang berdoa: "Ya Tuhan kami, berilah kami kebaikan di dunia dan kebaikan di akhirat dan peliharalah kami dari siksa neraka." (Q.S. Al-Baqarah (2): 201).

Menurut Mahmud Yunus, ayat tersebut menggambarkan bahwa seorang Muslim secara fitrah menghendaki kebahagiaan hidup di dunia dan akhirat. Kebahagiaan itu akan dia dapatkan dengan usahanya sendiri. Oleh sebab itu setiap pribadi Muslim harus berusaha secara aktif dan maksimal untuk mencapai kebahagiaan hidup di dunia dan akhirat. ${ }^{15}$ Tujuan pendidikan menurut Mahmud Yunus ini sejalan dengan tujuan pendidikan Islam yang dirumuskan Ramayulis, ${ }^{16}$ bahwa salah satu tujuan tertinggi dari pendidikan Islam adalah untuk memperoleh kesejahteraan kebahagiaan hidup di dunia sampai akhirat, baik individu maupun masyarakat.

Dari seluruh rumusan tujuan pendidikan yang dapat dijumpai dalam literatur pendidikan Islam, Mahmud Yunus menilai bahwa yang lebih utama dan terpenting adalah pendidikan akhlak, karena Rasulullah SAW. diutus ke permukaan bumi adalah untuk memperbaiki akhlak dan budi pekerti manusia. ${ }^{17}$ Atas dasar pemikiran tersebut menurut Mahmud Yunus, tugas yang utama dan pertama yang menjadi beban para ulama, guru-guru agama dan pemimpin Islam adalah mendidik anak generasi muda, dan masyarakat, dengan tujuan agar mereka memiliki akhlak yang santun dan berbudi pekerti yang mulia. Hal yang demikian tidak berarti bahwa pendidikan jasmani, dan kecakapan fisik tidak perlu, melainkan akhlak merupakan prioritas utama pendidikan.

Selanjutnya Mahmud Yunus merumuskan macam-macam tujuan pendidikan Islam:

\section{a. Tujuan pendidikan jasmani (al-ahdaf al-jismiyyah)}

Menurut Mahmud Yunus, ${ }^{18}$ salah satu dasar pokok untuk mendapat kemajuan dalam kehidupan ialah bila peserta didik dibekali kefahaman akan arti pentingnya menjaga potensi fisik. Beliau mencontohkan bahwa pada zaman dahulu para pendidik mengabaikan pendidikan jasmani, mereka belajar di dalam bilik yang gelap, tidak

${ }^{15}$ Ibid., h. 11

${ }^{16}$ Ramayulis, Ilmu Pendidikan Islam, (Jakarta: Kalam Mulia, 2008), cet ke-6, h. 135-136

${ }^{17}$ Mahmud Yunus mengutip hadis Rasulallah SAW: انما بعث لاتمم ملكار الأخلاق (Sesungguhnya aku diutus oleh Allah untuk menyempurnakan akhlak). Kemudian Mahmud Yunus juga menyandarkan pemikiran pada Firman Allah SWT.: 'وَإِنَّك لَعَلَن خُلْقِ عَظِيمٍِ (Dan sesungguhnya kamu(Muhammad SAW) benar-benar berbudi pekerti yang agung). (Q.S. Al-Qalam [68]: 4).

${ }^{18}$ Mahmud Yunus, Pokok-pokok ..., h.19-20 
berjendela, tidak ada cahaya matahari yang masuk, sehingga sangat membahayakan kesehatan anak-anak didik. Oleh sebab itu menurut beliau pola pendidikan seperti ini harus dirubah, pendidik harus betul-betul memperhatikan kesehatan jasmani anak didik, udara tempat belajar harus bersih, cahaya matahari harus masuk, dan pendidik hendaknya menyediakan tempat anak-anak berolahraga, seperti: berenang, berlari, memanah, berdayung, dan lainnya. Dari kegiatan aktifitas inilah akan muncul peserta didik yang kuat fisiknya, tangkas, dan terhindar dari berbagai macam penyakit.

Mahmud Yunus mengutip pendapat Imam al-Ghazali, ${ }^{19}$ yang menyatakan bahwa Sepatutnya anak-anak diizinkan bermain setelah pulang dari sekolah, yaitu permainan yang indah, supaya ia istirahat dari kelelahan belajar, namun jangan sampai berlebihan. Tindakan yang melarang anak-anak bermain dan memaksanya belajar terus menerus akan mematikan hati anak-anak dan merusak kecerdasannya dan menyusahkan kehidupannya, ia akan berontak dan melakukan tindakan negative supaya terbebas dari kegiatan belajar itu.

Selanjutnya Mahmud Yunus mengutip salah satu ayat al-Qur`an dan Hadis Nabi Muhammad SAW. di antaranya firman Allah SWT.:

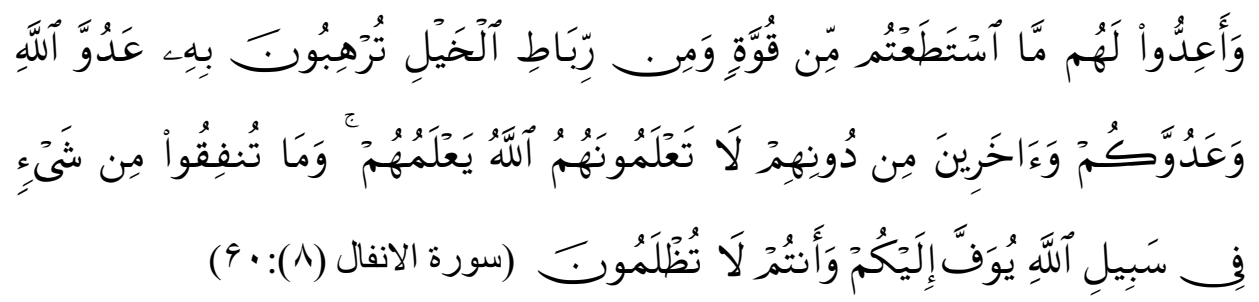

"Dan siapkanlah untuk menghadapi mereka kekuatan apa saja yang kamu sanggupi dan dari kuda-kuda yang ditambat untuk berperang (yang dengan persiapan itu) kamu menggentarkan musuh Allah dan

19 Al-Ghazali, adalah ulama yang amat berpengaruh dan dimuliakan di dunia Islam. Gelarnya antara lain adalah Hujjät al-Islām, yang bermakna bukti kebenaran Islam. Ia dilahirkan di desa Gazaleh, dekat Tus, Iran Utara, pada $1058(450 \mathrm{H})$. Setelah dididik dalam lingkungan keluarga dan guru yang zahid pada masa kecilnya, kemudia ia belajar di madrasah Nizamiyah di Tus. Jurjan, dan Nisyapur. Di Nisyapur inilah ia berguru dan bergaul dengan Imam al-Juwaini. Selanjutnya ia berada di Mu'askar dan Bagdad (1090 5/ 4838 H). di Bagdad ini ia menjadi pimpinan madrasah Nizamiyah dan guru besar yang amat disegani. Didahului oleh konflik bathin yang parah (karena sama kuatnya tarikan untuk tetap berada di Bagdad dan dorongan untuk meninggalkannya) kemudia beliau sakit selama enam bulan, bahkan tidak bisa berbicara, ia tinggalkan kota Bagdad dan berkhalwat menjalani kehidupan tasawuf selama 10 tahun di Damaskus, Yerussalem, Mekah, Madinah, dan Tus. Setelah itu ia mengajar lagi selama dua tahun di Nisyapur, kemudian kembali ke Tus dan mendirikan madrasah untuk para calon ahli fikih dan para calon sufi. Di Thus inilah beliau wafat dalam usia 55 tahun $(1111 / 505 \mathrm{H})$. Imam al-Ghazali selain mahir berbicara juga merupakan ulama yang produktif. Karya tulisnya relatif banyak, lebih dari 228 buku atau risalah, dalam berbagai disiplin ilmu: tasawuf, teologi, falsafat, logika, fiqih, pendidikan dan ilmu lainnya. Lihat: Harun Nasution dkk., Ensiklopedi Islam Indonesia (Jakarta: Penerbit Djambatan, 1992), h. 257 
musuhmu dan orang orang selain mereka yang kamu tidak mengetahuinya; sedang Allah mengetahuinya. apa saja yang kamu nafkahkan pada jalan Allah niscaya akan dibalasi dengan cukup kepadamu dan kamu tidak akan dianiaya (dirugikan)." (Q.S. al-Anfal, 8: $60)$.

Sabda Rasulullah SAW.:

$$
\text { المؤمن القوي خير وأحب الى الله من المؤمن الضعيف وفي كل خير (رواه مسلم) }
$$

"Seorang mukmin yang kuat lebih baik dan lebih disukai Allah daripada mukmin yang lemah, dan masing-masing ada kebaikan." (H.R. Muslim) ${ }^{20}$

Dari uraian di atas dapat dikatakan bahwa tujuan pendidikan jasmani dalam Islam adalah membentuk manusia Muslim yang sehat dan kuat jasmaninya serta memiliki keterampilan yang tinggi.

b. Tujuan pendidikan akal (al-ahdaf al-'qliyah)

Di samping tujuan jasmani menurut Mahmud Yunus pendidikan Islam juga memperhatikan tujuan akal, supaya anak didik mendapat pengetahuan dan mencerdaskan akal pikiran serta cakap memanfaatkan ilmu yang diperoleh sehingga memberi manfaat bagi dirinya dan bagi masyarakat sekitarnya. Terhadap cara belajar yang hanya mengandalkan sistem hafalan dalam menentukan kelulusan peserta didik untuk mendapat angka-angka, menurut beliau adalah kurang tepat. Seharusnya di samping menghafal, anak didik juga harus dilatih daya ingatnya, memperkuat kemauannya, menghidupkan perasaan, dan melakukan kebiasaan positif, seperti jujur, rajin dan taat kepada gurunya. ${ }^{21}$ Pendapat Mahmud Yunus ini sejalan dengan pendapat Ramayulis yang menyatakan bahwa aspek tujuan pendidikan akal bertumpu pada pengembangan intelegensia yang berada dalam otak. Dengan pendidikan akal manusia dapat menggunakan kecerdasannya untuk meneliti, menganalisis keajaiban ciptaan Allah. $^{22}$

\section{c. Tujuan pendidikan akhlak (al-ahdaf al-khuluqiyah)}

Mahmud Yunus berpendapat bahwa tujuan pendidikan akhlak adalah untuk menyiapkan peserta didik yang berakhlak mulia, berbudi luhur, bercita-cita tinggi,

\footnotetext{
${ }^{20}$ Muslim, Shâhih ..., hadis no. 6.945

${ }^{21}$ Mahmud Yunus, Pokok-pokok ..., h. 21-22

${ }^{22}$ Ramayulis, Ilmu ..., h. 145
} 
berkemauan keras, beradab sopan santun, baik tingkah lakunya, manis tutur bahasanya, jujur dalam segala perbuatannya, dan suci murni hatinya. ${ }^{23}$

Selanjutnya Mahmud Yunus menjelaskan kaidah-kaidah khusus dalam memperkenalkan dan mengajarkan akhlak kepada peserta didik, di antaranya: Pertama, dengan menceritakan orang-orang terdahulu yang berakhlak mulia dan berbudi luhur, karena cerita itu sangat berpengaruh terhadap peserta didik; kedua, mengamalkan dan membiasakan budi pekerti yang baik; ketiga, ikutan yang baik untuk di tiru dan diteladani, makanya harus dimulai dari pendidik itu sendiri; keempat, pergaulan yang baik; kelima,mengatur permainan yang akan memunculkan akhlak yang baik, seperti bertolong-tolongan; keenam, pelajaran akhlak harus dimasukan dalam pelajaranpelajaran umum; dan, ketujuh, mempelajari ilmu akhlak itu sendiri. ${ }^{24}$

d. Tujuan pendidikan kemasyarakatan (al-ahdaf al-ijtima'iyah)

Mahmud Yunus berpandangan bahwa pendidikan Islam hendaknya memperkenalkan kehidupan bermasyarakat kepada peserta didik sejak dari dini. Hal ini dimaksudkan agar mereka tidak mementingkan diri sendiri, dan mengabaikan orang di sekitarnya. $^{25}$ Tujuan pendidikan sosial ini penting artinya karena manusia sebagai khalifah Allah di muka bumi tidak bisa hidup tanpa bantuan dan pertolongan orang lain.

e. Tujuan pendidikan kesenian (keindahan)

Anak-anak semenjak terlahir ke dunia mempunyai gharizah (instink) suka dan cenderung kepada keindahan. Mahmud Yunus berpendapat bahwa tujuan pendidikan keindahan adalah mendidik anak-anak supaya cenderung kepada keindahan, menghargai yang bagus, dan cenderung kepada yang cantik dan tertata rapi. Dari proses pendidikan ini maka akan lahir perasaan halus, menilai, menyusun dan menata sesuatu dengan rapi yang mencerminkan akhlak dan keperibadiannya.

Berdasarkan uraian di atas jelaslah bahwa tujuan pendidikan Islam menurut Mahmud Yunus adalah mendorong seseorang agar mengamalkan ajaran Islam secara sempurna (kaffah), yaitu ajaran yang menyeluruh, artinya peserta didik tidak hanya menguasai ilmu ukhrawi namun juga ilmu duniawi secara berimbang dan dihiasi dengan akhlak mulia, sehingga tercapai kebahagiaan hidup dunia dan akhirat. Orang yang

${ }^{23}$ Ibid., h. 22

${ }^{24}$ Mahmud Yunus, Metodik Khusus Pendidikan Agama, (Jakarta: Hidakarya Agung, 1980), Cet. ke-10, h. 33-37

${ }^{25}$ Ibid., h. 23-24 
demikian itulah yang kelak akan dapat diserahi melaksanakan tugas sebagai pemimpin umat. Rumusan tujuan pendidikan Mahmud Yunus ini memperlihatkan dengan jelas adanya pengaruh lingkungan masyarakat Islam di Minang Kabau saat itu, yaitu masyarakat yang kemajuannya tidak seimbang. Mereka hanya mementingkan urusan ukhrawi saja dan mengabaikan urusan duniawi. Mahmud Yunus kelihatannya ingin membawa umat Islam maju secara seimbang antara kehidupan duniawi dan ukhrawi dengan pendidikan sebagai alatnya.

\section{Kurikulum Pendidikan Islam}

Dalam hal kurikulum pendidikan, Mahmud Yunus memiliki pandangan dan gagasan yang pada masa itu tergolong baru, dan di masa sekarang tampak masih cukup

relevan untuk digunakan. Beliau berusaha merefleksikan keseimbangan antara ilmu agama dan ilmu umum yang saat itu belum dikenal di madrasah tradisional. Hal ini dapat dilihat pada kurikulum Normal Islam Padang:

a. Ilmu-ilmu Agama:

(1) Tafsir al-Qur'an

(2) Hadis

(3) Fiqh/Ushul Fiqh

b. Ilmu Bahasa Arab:

(1) Insyak

(2) Muthalaah

(3) Mahfuzat

(4) Qawa'id

(5) Adab al-Lughah

c. Ilmu-ilmu Umum:

(1) Aljabar

(2) Ilmu Ukur

(3) Ilmu Alam/Kimia

(4) Ilmu Hayat/ Geologi

(5) Ekonomi

(6) Tarekh Islam

(7) Sejarah Indonesia/ Dunia

(8) Ilmu Bumi/ Ilmu Falak 
(9) Tata Negara

(10) Bahasa Inggris/ Belanda

(11) Gerak Bidang

(12) Ilmu Pendidikan

(13) Ilmu Jiwa

(14) Ilmu Kesehatan

(15) Khat/ Menggambar.

Tentang pengalokasian waktu dapat dilihat sebagai berikut:

Tabel II: Pelajaran Normal Islam Padang Tahun $1931^{26}$

\begin{tabular}{|c|c|c|c|c|c|}
\hline No & Mata Pelajaran & Kelas I & Kelas II & Kelas III & Kelas IV \\
\hline 1. & Ilmu-ilmu Agama $^{27}$ & 6 & 6 & 5 & 4 \\
\hline \multirow[t]{6}{*}{2.} & Bahasa Arab: & 8 & 8 & 8 & 8 \\
\hline & a. Mengarang/berpidato & 2 & 2 & 2 & 2 \\
\hline & b. Muthala'ah & 2 & 2 & 2 & 2 \\
\hline & c. Mahfuzat & 1 & 1 & 1 & 1 \\
\hline & d. Qawaid & 2 & 2 & 2 & 2 \\
\hline & e. Adab al-Lughah & 2 & 2 & 2 & 2 \\
\hline 3. & Al-Jabar & 2 & 2 & 2 & 2 \\
\hline 4. & Ilmu Ukur & 1 & 1 & 1 & 1 \\
\hline 5. & Ilmu Alam/Kimia & 2 & 2 & 2 & 2 \\
\hline 6. & Ilmu Hayat/Geology & 1 & 1 & 1 & 1 \\
\hline 7. & Ekonomi & - & - & 1 & 1 \\
\hline 8. & Tarikh Islam & 1 & 1 & 1 & 1 \\
\hline 9. & Sejarah Indonesia/ Dunia & 2 & 2 & 2 & 2 \\
\hline 10. & Ilmu Bumi/Falak & 2 & 2 & 2 & 2 \\
\hline 11. & Tata Negara & 1 & 1 & - & - \\
\hline 12. & Bahasa Inggeris/ Belanda & 3 & 3 & 3 & 3 \\
\hline 13. & Gerak Badan & 1 & 1 & 1 & 1 \\
\hline 14. & Ilmu Pendidikan & 2 & 2 & 3 & 4 \\
\hline 15. & Ilmu Jiwa & - & - & 1 & 1 \\
\hline 16. & Ilmu Kesehatan & 1 & 1 & - & - \\
\hline \multirow[t]{2}{*}{17.} & Khat/menggambar & 1 & 1 & 1 & 1 \\
\hline & Jumlah & 34 & 34 & 34 & 34 \\
\hline
\end{tabular}

Dari gambaran jam pelajaran di atas dapat dipahami bahwa kurikulum Normal Islam lebih memprioritaskan ilmu pengetahuan umum dibandingkan dengan ilmu

${ }^{26}$ Mahmud Yunus, Sejarah Pendidikan Islam di Indonesia, (Jakarta: Mutiara, 1979), Cet ke-2, h.

${ }^{27}$ Pelajaran Agama tidak banyak lagi diajarkan, sebab pelajar-pelajar yang masuk Normal Islam telah belajar ilmu Agama selama 7 tahun lamanya (Thawalib/Diniyah atau Tarbiah Islamiah). 
pengetahuan Agama dan bahasa Arab. Kemudian penempatan waktu (alokasi) yang diberikan untuk ilmu pengetahuan agama hanya sekitar 15\%, bahasa Arab 20\%, dan $65 \%$ alokasi waktu yang tersedia untuk mentransformasikan ilmu-ilmu umum. Terjadinya pengalokasian waktu yang terlalu kecil untuk ilmu agama disebabkan siswa yang diterima di Normal Islam adalah tamatan madrasah enam dan tujuh $\operatorname{tahun}^{28}$ yang sepanjang waktunya bersentuhan dengan pembelajaran agama.

Tabel. III: Pelajaran Madrasah Diniyah Puteri tahun $1928^{29}$

\begin{tabular}{llcccccc}
\hline No & \multicolumn{1}{c}{$\begin{array}{c}\text { Nama Mata } \\
\text { Pelajaran }\end{array}$} & $\begin{array}{c}\text { Kelas } \\
\text { I }\end{array}$ & $\begin{array}{c}\text { Kelas } \\
\text { II }\end{array}$ & $\begin{array}{c}\text { Kelas } \\
\text { III }\end{array}$ & $\begin{array}{c}\text { Kelas } \\
\text { IV }\end{array}$ & $\begin{array}{c}\text { Kelas } \\
\text { V }\end{array}$ & $\begin{array}{c}\text { Kelas } \\
\text { VI }\end{array}$ \\
\hline 1. & Fiqh & 4 & 4 & 4 & 3 & 3 & 3 \\
\hline 2. & Tafsir & 3 & 3 & 3 & 3 & 3 & 2 \\
\hline 3. & Tauhid & 2 & 2 & 2 & 2 & 2 & 1 \\
\hline 4. & Hikmah Tasryi' & - & - & - & 2 & 1 & 1 \\
\hline 5. & Adab (akhlak) & 2 & 2 & 2 & 1 & 1 & 1 \\
\hline 6. & Hadits & 2 & 1 & 1 & 1 & 1 & 1 \\
\hline 7. & Nahu & 3 & 3 & 3 & 3 & 3 & 3 \\
\hline 8. & Sharaf & - & 2 & 2 & 3 & 3 & 3 \\
\hline 9. & Ilmu Bumi & 2 & 1 & 1 & 1 & 1 & 1 \\
\hline 10. & Ushul Fiqhi & - & - & - & - & - & 2 \\
\hline 11. & Arudl & - & - & - & - & 1 & 1 \\
\hline 12. & Tarikh Islam & 2 & 2 & 2 & 2 & 2 & 2 \\
\hline 13. & Menulis Arab & 2 & 2 & 2 & 1 & 1 & 1 \\
\hline & $\quad$ Jumlah & 22 & 22 & 22 & 22 & 22 & 22 \\
\hline
\end{tabular}

Dari tabel di atas terlihat dan tergambar bahwa apa yang disampaikan Mahmud Yunus tentang madrasah-madrasah awal yang telah banyak memformatkan mata pelajaran agama dalam pembelajaran mereka. Seperti pada Madrasah Diniyah Puteri tahun 1928 tersebut, selama enam tahun siswa belajar hanya 1 pelajaran umum yang diperkenalkan kepada siswa yakni ilmu bumi, selebihnya pelajaran agama semua. Melalui sekolah Normal Islam yang dipimpinnya Mahmud Yunus berusaha ingin memperkenalkan pelajaran umum yang lebih banyak kepada siswanya.

Meskipun materi ilmu pengetahuan umum lebih besar porsinya dari ilmu pengetahuan agama, bagi Mahmud Yunus prioritas pendidikan sebenarnya terletak pada pembentukan keperibadian dan pendidikan moral. Oleh karena itu menurut Mahmud

${ }^{28}$ Sekolah-sekolah yang menerapkan enam tahun masa belajar seperti: Madrasah Diniyah Puteri Tahun 1928, sedangkan yang menerapkan masa belajar tujuh tahun adalah Sumatera Thawalib, Madrasah Diniah dan Thawalib. Baca Mahmud Yunus, Sejarah ..., h. 72, 75, dan 109

${ }^{29}$ Ibid. 
Yunus, semua mata pelajaran baik pengetahuan agama maupun pengetahuan umum bermuara pada tujuan pendidikan Islam, yaitu membentuk insan kamil yang taqwa kepada Allah, cerdas, cakap, terampil, tangkas dan berkepribadian utama yang diridhai Allah SWT.

Berkaitan dengan kurikulum pengajaran bahasa Arab, Mahmud Yunus menawarkan kurikulum pengajaran bahasa Arab yang integrated antara satu cabang dengan cabang lainnya dalam ilmu bahasa Arab. Seorang anak didik diberikan cabangcabang ilmu bahasa Arab yang dipadukan dengan menerapkannya dalam pergaulan sehari-hari. Menurut Mahmud Yunus, jika sekolah-sekolah swasta Belanda seperti HIS, Mulo, dan HIK, bahasa Belanda dijadikan sebagai bahasa pengantar, maka beliau menerapkan di madrasah supaya bahasa Arab dijadikan bahasa pengantar dalam mempelajari ilmu agama Islam dan ilmu-ilmu lainnya. ${ }^{30}$

Dalam menerapkan kurikulum barunya dalam bidang pengajaran bahasa Arab, Mahmud Yunus mengarang buku pelajaran bahasa Arab yang berjudul Durus alLughah al-Arabiyah sebanyak 4 jilid $^{31}$. Dalam buku tersebut Mahmud Yunus menerapkan cara pembelajaran bahasa Arab yang menerapkan dan memadukan unsur membaca, menulis, memahami, dan berbicara dengan menggunakan bahasa Arab. Buku yang dikarangnya pada saat ia berada di Mesir, mulai dilaksanakan pada tahun 1931 ketika ia mengajar di Madrasah al-Jami'ah al-Islamiyah (1931-1932) dan Normal Islam (1931-1946) yang diberi nama dengan Kulliyat al-Mu'allimin al-Islamiyah Normal Islam Padang.

Dalam hal pemantapan kurikulum pada madrasah-madrasah yang beliau pimpin, Mahmud Yunus juga berusaha mengembangkan penafsiran al-Qur`an pola penafsiran Indonesia modern, yaitu karya-karya tafsir yang terbit mulai paruh ke 2 abad ke-20. ${ }^{32}$ Bahkan dalam catatan Howard Federspiel, Tafsir al-Qur`an al-Karim karya Mahmud Yunus tergolong sebagai hasil karya terjemahan al-Qur`an generasi pertama bersama Tafsir al-Furqan karya Ahmad Hasan. ${ }^{33}$

\footnotetext{
${ }^{30}$ Mahmud Yunus, Riwayat ..., h. 46

31 Didin Syafruddin, "Mahmud Yunus wa Ijtihatuhu fi Tajdid Ta'lim al-Lughah al-Arabiyah," Studia Islamika, Vol. 2, No. 3, 1995, h. 176

${ }^{32}$ M. Anwar Syarifuddin, dan Jauhar Azizy, "Mahmud Yunus: Pelopor Pola Baru Penulisan Tafsir al-Qurān Indonesia," Ilmu Ushuluddin, Volume 2, Nomor 3, Januari-Juni 2015, h. 323

${ }_{33}$ Howard Federspiel, Kajian al-Qur'an di Indonesia, Terj. Tajul Arifin, (Bandung: Mizan, 1996), h. 137
} 
Mahmud Yunus juga menitik beratkan pada kajian pendalaman fiqh Islam hal ini ditunjukkan dengan kemahiran Mahmud Yunus dalam menguasai fiqh/hukum Islam terbukti ditemukan banyak hasil pemikiran dan karya-karya beliau dalam bidang fiqh. Karya-karya fiqhnya setakat ini tetap digunakan sebagai rujukan di pelbagai madrasah, pondok, bahkan juga institusi pengajian tinggi di Indonesia. Sampai saat ini, jumlah karya-karya Mahmud Yunus dalam bidang fiqh tersebut adalah sebanyak 17 buah. ${ }^{34}$

Dari penjelasan di atas terlihat bahwa dalam pemikiran Mahmud Yunus kurikulum pendidikan merupakan unsur penting dan tidak bisa terpisahkan dalam proses pembelajaran. Beliau juga tidak memisahkan antara mata pelajaran umum dan mata pelajaran agama (integrated).

\section{Kelembagaan Pendidikan Islam}

Menurut Mahmud Yunus ada tiga kelembagaan yang memberikan pengaruh dalam membentuk pribadi dan karakter seorang anak, yaitu:

Pertama, lembaga pendidikan pertama menurut Mahmud Yunus adalah rumah tangga. ${ }^{35}$ Rumah tangga mempunyai pengaruh yang besar sekali dalam pembentukan watak dan karakter anak-anak. Pendidikan di rumah ini ditekankan pada pembinaan watak, karakter, kepribadian, keterampilan mengerjakan pekerjaan atau tugas keseharian yang biasa dikerjakan di rumah tangga. Mahmud Yunus mengutip pendapat Hafiz Ibrahim: "Ibu itu bagai sekolah, mengeluarkan umat yang baik budi. Ibu itu laksana taman, menghasilkan buah lezat rasanya. Ibu itu guru segala guru, berpengaruh sampai ke ufuk langit."

Selanjutnya Mahmud Yunus, menekankan bahwa pendidikan di rumah tangga ditekankan pada pembinaan budi bahasa dan tutur kata, pada adab dan akhlak anak, dan pada penghalusan perasaan dan menumbuhkan nilai-nilai keindahan dalam jiwa anak. Rumah tempat penanaman akidah, bimbingan membaca dan menghafal al-Qur'an, praktik ibadah, dan praktek melakukan akhlak mulia, baik terhadap ayah ibu, dan anggota keluarga lainnya.

Kedua, lembaga pendidikan kedua menurut Mahmud Yunus, adalah sekolah (madrasah). Sekolah adalah tempat mendidik dan mengajar anak-anak, yang mempunyai peraturan dan ketentuan yang harus ditaati murid-murid (formalisasi).

\footnotetext{
34 Eficandra Masril, Mohd. Nasiran Mohamad, Muhammad Adib Samsudin, Anwar Fakhri Omar, "Pemikiran Fiqh Mahmud Yunus (Fiqh Thought of Mahmud Yunus)," Islamiyat 35 (1), 2013, h. 7

${ }^{35}$ Mahmud Yunus, Pokok-pokok ..., h. 27-28
} 
Menurut Mahmud Yunus, sekolah merupakan rumah tangga terbesar, karena di sana berkumpul seluruh komponen pendidikan ada guru, murid, proses pembelajaran, peralatan pembelajaran. Tugas sekolah bukan semata-mata mengajar anak membaca, menulis dan berhitung, tetapi jauh lebih penting dari itu sekolah berusaha mempersiapkan anak untuk mengisi kebutuhan masyarakat tempat tinggalnya dan menempuh kehidupan yang sempurna. ${ }^{36}$

Untuk mewujudkan dan melahirkan anak didik seperti yang disebutkan di atas, maka perlu mempersiapkan guru-guru yang cakap dan ahli, mempunyai minat dan kemauan mendidik yang kuat, mempunyai pengetahuan tentang ilmu jiwa peserta didik, pengetahuan dan keterampilan cara mendidik dengan pendekatan pendidikan modern. Tugas guru sangat berat namun harus ia jalankan dengan ikhlas. Menurut Mahmud Yunus, guru harus melatih tubuh anak didik supaya tegap dan sehat, mendidik tangannya supaya terampil bekerja, mendidik akal dan otaknya supaya mempunyai pemikiran yang cemerlang dan dapat mengambil keputusan yang tepat, mendidik hatinya supaya suka menerima kebenaran, mendidik matanya supaya suka melihat keindahan, mendidik telingahnya supaya terbiasa mendengarkan yang baik dan bermakna. $^{37}$

Ketiga, lembaga pendidikan yang berpengaruh dalam pendidikan anak-anak adalah lingkungan dan pergaulan masyarakat. ${ }^{38}$ Menurut Mahmud Yunus, lingkungan dan alam sekitar anak-anak, serta teman sejawatnya mempunyai pengaruh yang besar sekali dalam pembentukkan akhlak anak. Lingkungan yang baik akan melahirkan anakanak yang berhati mulia, dan sebaliknya lingkungan yang jahat akan melahirkan anakanak yang melakukan tindakan terpuji. ${ }^{39}$

Selanjutnya dalam hal kelembagaan ini, terlihat bahwa Mahmud Yunus termasuk orang yang mempelopori perlunya merubah sistem pengajaran dari yang bercorak individual kepada sistem pengajaran klasikal. Diketahui bahwa pada sistem individual sebagaimana diterapkan di pesantren-pesantren menggunakan metode sorogan atau weton (bandungan). ${ }^{40}$

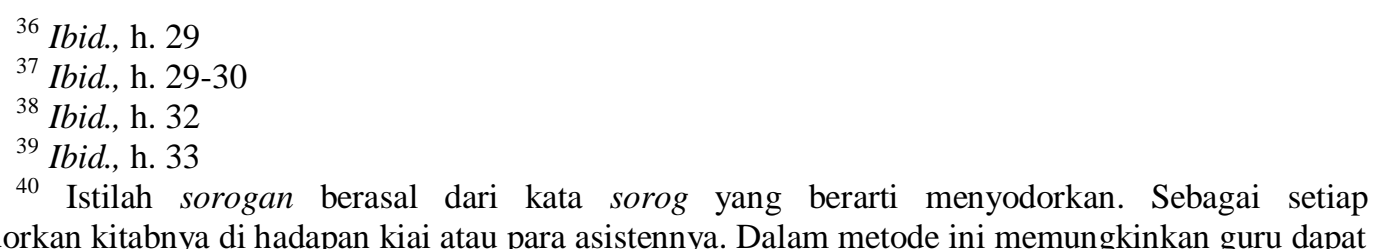
menyodorkan kitabnya di hadapan kiai atau para asistennya. Dalam metode ini memungkinkan guru dapat 
Sehubungan dengan kelembagaan pendidikan tersebut di atas, Mahmud Yunus memperkenalkan Kulliyah al-Muallimin al-Islamiyah (KMI) atau Normal Islam pada tanggal 1 April 1931, di mana pelaksanaan pengajaran dilaksanakan di kelas-kelas dengan jadwal dan kurikulum yang sudah ditetapkan. Adapun rencana mata pelajarannya adalah: ${ }^{41}$
a. Ilmu-ilmu Agama
b. Ilmu Bahasa Arab dan kesusasteraannya.
c. Pengetahuan Umum:

1) Berhitung dagang

2) Aljabar

3) Ilmu ukur

4) Ilmu alam/ kimiah

5) Ilmu hayat/geologi

6) Ekonomi

7) Memegang buku

8) Sejarah Dunia/ Islam

9) Ilmu bumi/falak

10) Tata Negara

11) Bahasa Inggris/Belanda

12) Gerak Badan.

d. Ilmu mendidik dan mengajar

e. Ilmu Jiwa

f. Ilmu Kesehatan

Namun pada pelaksanaannya rencana pengajaran madrasah-madrasah mu'allimin, tidak sama bagi madrasah-madrasah itu. Jadi ada yang mengajarkan semua ilmu-ilmu tersebut dan ada pula yang mengajarkan hanya sebagian saja, tergantung kebijakan guru yang sedang mengajar. ${ }^{42}$

mengawasi dan membimbing kemampuan muridnya secara maksimal. Metode ini menuntut kesabaran murid dan guru. Tidak terdapat aturan formal dalam pola ini termasuk soal waktu. Biasanya banyak atau sedikitnya waktu yang digunakan tergantung pada kemampuan murid menangkap dan mencerna. Lihat Manfred Oepen dan Walfgang Karcher (ed.), The Impact of Pesantren in Education and Community Development in Indonesia, (Jakarta: P3M, 1998), h. 21

${ }^{41}$ Mahmud Yunus, Sejarah ..., h. 104

42 Ibid. 
Jika dianalisis pemikiran Mahmud Yunus tentang kelembagaan ini agaknya dapat dikatakan bahwa Mahmud Yunus termasuk orang yang mempelopori perlunya merubah sistem pengajaran dari yang bercorak individual kepada sistem pengajaran klasikal. Hal ini menunjukkan bahwa Mahmud Yunus menekankan bahwa guru mesti mengawasi dan membimbing muridnya dan mengarahkan potensi mereka secara maksimal, dengan penuh kesabaran.

\section{Metode Pembelajaran dalam Pendidikan Islam}

Dalam proses pembelajaran, metode mempunyai kedudukan yang sangat penting dalam upaya mencapai tujuan. Tanpa metode suatu materi pelajaran tidak akan berjalan secara efesien dan efektif dalam pembelajaran. Mahmud Yunus mengungkapkan: “althariqah ahammu min al-maddah." ${ }^{, 43}$ Artinya metode mengajar lebih penting dari materi pembelajaran. Menurut Mahmud Yunus, metode adalah jalan yang akan ditempuh oleh guru untuk memberikan berbagai jenis mata pelajaran. Jalan itu adalah khittah (garis) yang direncanakan sebelum masuk ke dalam kelas dan dilaksanakan di dalam kelas pada saat mengajar. Oleh sebab itu, seorang guru harus menguasai metode yang akan digunakannya dan mampu mendorong murid-muridnya berfikir dan bukan menghafal saja. Seorang guru harus menggunakan metode yang efisien dan efektif, sehingga tidak melelahkan dan membosankan murid, serta beragam dalam penggunaannya. Menurutnya banyak guru yang menguasai materi, namun kesulitan dalam menyampaikannya.

Sehubungan dengan menerapkan metode pada suatu mata pelajaran, Mahmud Yunus, juga sangat memperhatikan psikologi anak didik sesuai dengan kaidah-kaidah pengajaran modern, dengan tujuan agar pelajaran dapat difahami dan diingat secara kritis oleh murid. Selanjutnya ia juga menekankan tentang pentingnya penanaman moral dalam proses pembelajaran, karena moralitas adalah merupakan bagian yang tak terpisahkan, dan sangat penting dari sistem pendidikan Islam.

Ada beberapa pemikiran moderat Mahmud Yunus tentang metode pendidikan yang dirasa baru saat itu, namun masih eksis sampai sekarang ini:

Pertama, Mahmud Yunus telah berhasil meletakkan dan menulis secara khusus metode mengajarkan keimanan, ibadat, akhlak, dan sejarah Islam untuk anak-anak, remaja dan dewasa. Kiprahnya yang demikian memperlihatkan bahwa konsep yang

${ }^{43}$ Mahmud Yunus, Pokok-pokok ..., h. 85. Ungkapan ini disambung oleh Fajar Malik, "walakin mиdarrisu ahaтти min al-thariqah" artinya: ...tetapi guru lebih penting dari metode. 
dirumuskan dan disosialisasikannya itu benar-benar komprehensif (menyeluruh), mencakup aspek kognitif, afektif, dan psikomotorik. Aspek kognitif karena dalam kegiatan belajar mengajar, Mahmud Yunus lebih menekankan pada pendalaman materi untuk membawa murid berpikir secara kritis, sehingga para siswa dapat menggunakan penalarannya semaksimal mungkin. Aspek psikomotorik, karena dalam kegiatan belajar mengajar, Mahmud Yunus lebih menekankan pada pengembangan kecakapan murid semaksimal mungkin, sehingga seorang anak selain cerdas, juga mampu mengaplikasikan ilmu yang dipelajarinya di tengah-tengah masyarakat. Sedangkan aspek afektif, terlihat dari caranya yang menekankan pentingnya seorang guru menanamkan moral dan akhlak kepada siswa.

Mahmud Yunus memperkenalkan buku pegangan bagi guru-guru agama yang berisi tentang cara mengajarkan agama yang sebaik-baiknya kepada peserta didik sesuai dengan tingkat usia dan jenjang pendidikan yang sedang diikutinya. Berkaitan ini beliau menulis buku yang berjudul Metodik Khusus Pendidikan Agama. ${ }^{44}$ Buku ini berisi uraian tentang cara mengajarkan agama mulai dari tingkat Sekolah Dasar hingga Perguruan Tinggi. Di dalam buku tersebut, Mahmud Yunus mencoba merangkum beberapa kaidah mengajar, antara lain ketentuan tentang keharusan seorang guru agar menghubungkan pelajaran yang baru dengan pelajaran yang sebelumnya, hingga terjadi kesinambungan dan hubungan fungsional antara pelajaran-pelajaran yang diajarkan tersebut.

Selain itu dalam buku tersebut juga memberikan cara-cara membangkitkan minat dan perhatian peserta didik dengan cara mengaktifkan panca indera mereka, baik dengan lisan, tulisan, perbuatan, maupun alat peraga. Setelah pelajaran dibahas lalu disimpulkan dan diakhiri dengan latihan dan ulangan. Dengan cara demikian, peserta didik dilatih untuk berpikir dan mampu memecahkan masalah yang dihadapi dengan kekuatannya sendiri, dan agar pelajaran yang diberikan benar-benar dapat dikuasainya dengan baik.

Kedua, Mahmud Yunus menganjurkan agar menggunakan pendekatan integrated dalam mengajar pengetahuan agama dan umum. Ia menganjurkan agar pelajaran keimanan diintegrasikan dengan pelajaran ilmu tumbuh-tumbuhan, ilmu bumi,

\footnotetext{
${ }^{44}$ Mahmud Yunus, Metodik Khusus Pendidikan Agama; Metode Mengajarkan Pendidikan Agama di Sekolah Dasar, SMP, SMA, dan Fakultas Umum, Serta Metode Mengajarkan Ilmu Agama di PGAN 6 Tahun, (Jakarta: PT. Hidakarya Agung, 1980), cet. Ke-10
} 
ilmu alam, ilmu biologi, dan sebagainya. Selanjutnya sesuai dengan ketentuan dalam ilmu jiwa perkembangan, minat, keinginan, kesadaran anak untuk beribadah ditumbuh suburkan dengan cara melatih dan praktek langsung di tempat berwudhuk dan tempat shalat. Membiasakan mereka membaca basmalah pada setiap memulai pekerjaan, dan membaca hamdalah setiap selesai mengerjakan suatu pekerjaan. Demikian pula pelajaran tentang bermacam-macam shalat shalat fardhu dan sunnat, tata cara mengeluarkan zakat, cara berpuasa, dan cara menunaikan ibadah haji hendaknya tidak hanya diberikan teorinya saja melainkan harus dipraktekkan.

Dengan cara demikian, metode pengajaran tersebut selain bersifat integrated juga harus bertolak dari keinginan untuk memberdayakan peserta didik. Yaitu, mereka yang tidak hanya kaya dalam pengetahuan kognitif (to know), melainkan juga harus disertai dengan mempraktekkannya ( $t o d o$ ), menghayatinya dalam kehidupan sehari-hari (to act), dan mempergunakannya dalam kehidupan sehari-hari (to life together).

Selain itu Mahmud Yunus, menganjurkan agar setiap pelajaran yang disajikan dapat disesuaikan dengan waktu dan suasana serta menggunakan metode yang bervariasi. $^{45}$

Selanjutnya Mahmud Yunus menyarankan kepada para guru agar menggunakan metode yang tepat dengan cara mengetahui perkembangan jiwa anak didiknya. Untuk itu, dia memberi contoh tentang cara menanamkan keimanan, mendorong anak untuk beribadah dan memperhalus budi pekertinya melalui seni, khususnya nyanyian. Hal ini perlu dilakukan karena secara psikologis, jiwa anak-anak masih cendrung rekreatif dan bermain. Untuk hal ini, Mahmud Yunus menulis sebuah buku kecil yang berisi syair yang bertemakan keimanan, ibadah dan akhlak yang mulia. ${ }^{46}$

${ }^{45}$ Sekurang-kurangnya ada sepuluh metode cara mengajar yang Mahmud Yunus ungkapkan, yakni: (1) metode membahas dan menyimpulkan (the inductive methode); (2) metode mengqiaskan (the deductive method); (3) metode menghimpun antara membahas dan mengqiaskan; (4) metode memberitakan, berpidato atau berceramah; (5) metode bercakap-cakap dan bersoal jawab; (6) metode menyelidik: metode Dalton, metode Monteasori, metode berencana, metode Decroly; (7) metode mentakjubkan (appreciation); (8) metode latihan (drill); (9) metode menunjukkan (supervised study); dan (10) metode pemberian test (testing). Lihat: Mahmud Yunus: Pokok-pokok ..., h. 111

${ }^{46}$ Menurut Mahmud Yunus, anak-anak sejak terlahir ke dunia mempunyai gharizah (instink) suka kepada keindahan. Oleh sebab itu manusia menurut tabi'atnya mencintai segala yang indah. Mahmud Yunus mengutip hadis Nabi SAW: ان اله جم يل يحب الجم ال (Allah itu indah dan menyukai yang indah). Di antara syair yang dikarang Mahmud Yunus dan memuat uraian tentang keimanan, akhlak dan ibadah adalah: "Allah Maha Esa. Allah Maha Kuasa. Dialah yang memberi kita. Telinga dan mata. Pun kaki dan tangan. Anggota sekalian. Pun akal serta pikiran. Pemberian Tuhan. Allah yang Penyayang. Nikmat-Nya tak terbilang. Syukuri malam dan siang. Marilah Sembahyang." Lihat Mahmud Yunus, Pokok-pokok ..., h. 24-25 
Melalui syair nyanyian tersebut, seorang guru dapat menanamkan nilai-nilai keimanan kepada Allah SWT., akhlak yang mulia dan kepatuhan beribadah pada jiwa si anak. Melalui nyayian tersebut seorang anak diajak untuk mensyukuri segala nikmat yang dianugerahkan Tuhan, dengan cara melaksanakan ibadah, tanpa ada paksaan. Dengan demikian, secara mudah dan sederhana anak didik sudah mulai memperhatikan kejadian dirinya, kejadian makhluk dan alam besar di luar dirinya.

Dalam hal pengajaran bahasa Arab, Mahmud Yunus mempunyai metode khusus. Dengan metode ini ia menginginkan ulama Islam menguasai kemampuan bahasa Arab baik secara lisan, tulisan, maupun pemahamannya dengan baik. Ia memandang bahasa Arab selain sebagai bahasa pergaulan dunia Islam, juga merupakan bahasa ilmu-ilmu keIslaman. Keinginannya ini didasarkan pada hasil pengamatannya pada beberapa pesantren yang mengajarkan bahasa Arab, tetapi lulusannya tidak dapat berbicara secara aktif. Hal ini antara lain karena metode pengajarannya yang parsial. Yaitu, mengajarkan gramatika (nahwu sharaf) bahasa Arab secara hafalan tanpa dibarengi dengan mengaflikasikannya dalam percakapan dan tulisan. Akibat dari keadaan ini ulama Islam kurang memiliki kemampuan berkomunikasi dalam bahasa Arab. Untuk mengatasi masalah ini, Mahmud Yunus memperkenalkan metode al-thariqah al-mubasyarah atau direct method, metode langsung dengan pendekatan all in one system, yaitu seluruh komponen cabang ilmu bahasa Arab diajarkan secara integrated sambil mempraktikkannya dalam percakapan sehari-hari. Perubahan metode pengajaran bahasa Arab ini hasilnya amat signifikan, di mana para siswa lulusannya dapat berbicara, menulis, membaca, dan memahami literatur Arab dengan baik. Salah seorang murid Mahmud Yunus yang diajarkan bahasa Arab dengan metode yang demikian itu adalah Imam Zarkasyi yang selanjutnya beliau terapkan di Pesantren Modern Gontor. Hasilnya terlihat dengan jelas, di mana lulusan Pesantren Darussalam Gontor dapat berbicara, menulis, membaca, dan memahami literatur bahasa Arab dengan baik, hingga mendapat pengakuan dari Universitas al-Azhar, Kairo Mesir.

Mahmud Yunus juga menegaskan, bahwa metode pendidikan mempunyai asasasas dan pokok-pokok, yakni:

a) Mementingkan kecenderungan hati murid-murid dan kemauannya. Menurut Mahmud Yunus mata pelajaran yang diberikan kepada mereka haruslah 
sesuai dengan gharizah dan keinginannya, sesuai pula dengan lingkungan dan bakatnya.

b) Mempergunakan kegiatan yang terbit dalam hati murid sendiri, yakni dengan mengaktifkan peserta didik, memberikan kesempatan kepada peserta didik untuk mengembangkan pikiran dan kemampuan.

c) Mendidik dengan jalan bermain-main, yaitu permainan yang menumbuhkan kegembiraan dan kegirangan anak-anak.

d) Melakukan kaidah kebebasan yang teratur dalam mengajar, dan tidak membebani murid akan pekerjaan yang tidak sanggup mereka kerjakan.

e) Menarik hati murid-murid belajar dengan semangat yang datang dalam dirinya, sehingga melakukan pekerjaan berdasarkan panggilan jiwanya.

f) Memelihara alam kanak-kanak dan memikirkan masa depannya, yaitu berusaha untuk mempersiapkan anak-anak didik untuk kehidupan masa depan mereka.

g) Menumbuhkan semangat gotong royong dan rasa kebersamaan, antara murid dan guru, orang tua, dan lingkungan sekolah.

h) Memberanikan murid-murid belajar mandiri dan percaya akan kemampuan diri mereka sendiri.

i) Mempertajam panca indera dan kecerdasan intelektualnya secara seimbang. ${ }^{47}$

Dalam kaitannya dengan metode pendidikan sebagai salah satu dari komponen pendidikan Islam, Mahmud Yunus tidak menggunakan istilah pendidikan Islam sebagaimana yang digunakan tokoh pendidikan Islam seperti 'Athiyah al-Abrasyi akan tetapi dia menggunakan istilah metode pendidikan Agama, mengapa istilah 'agama' yang dia gunakan, hal itu karena menurutnya metode pendidikan agama adalah suatu cara bagaimana guru/ pendidik mengajarkan ilmu agama kepada peserta didiknya, sehinga ia menulis metode khusus bagaimana mengajarkan agama kepada peserta didik dari semenjak kanak-kanak sampai ke perguruan tinggi khususnya perguruan tinggi Islam. Walaupun metode yang diterapkan Mahmud Yunus masih relatif lebih tradisional daripada metode pendidikan Islam yang diusung oleh 'Athiyah. Karena berbeda dengan Mahmud Yunus yang menggunakan istilah metode pendidikan agama, dengan maksud menunjukkan cara-cara pembelajaran agama "Islam," maka 'Athiyah secara tegas

\footnotetext{
${ }^{47}$ Mahmud Yunus, Pokok-pokok ..., h. 95-96
} 
mengatakan bahwa dalam beberapa prinsip dasar, pendidikan Islam telah menunjukkan kemodernannya dengan memberikan kebebasan kepada peserta didik, memperhatikan bakat, kecenderungan, fitrah, kemampuan, serta keharusan berkomunikasi dengan kasih sayang kepada pesrta didik. ${ }^{48}$

Dari uraian Mahmud Yunus tentang metode pembelajaran di atas agaknya dapat dikatakan bahwa dia berpandangan metode pembelajaran hal yang sangat penting dan menentukan dalam pemberhasilan pembelajaran. Dan cara yang paling tepat menurutnya penggunaan metode disesuaikan dengan psikologis peserta didik, kecendrungan, potensi, gharizah, kemampuan dan bakat peserta didik.

\section{Akhlak dan Etika Pendidik}

Dalam pandangan Mahmud Yunus guru mempunyai tugas yang amat penting, ia berfungsi mengembangkan ilmu pengetahuan dan mampu memperbaiki kehidupan masyarakat. Guru menjadi contoh tauladan digugu dan ditiru, pengaruh guru terhadap murid-muridnya sama dengan pengaruh kedua orang tua terhadap anak-anaknya. ${ }^{49}$ Bahkan dalam pandangan Mahmud Yunus, guru itu merupakan warisan para Nabi, yang berfungsi menanamkan akhlak dan mengajarkan ilmu pengetahuan kepada muridmuridnya. Mahmud Yunus mengutip pendapat Syauqi: "Berdirilah terhadap guru dan sempurnakanlah kehormatan kepadanya, hampir guru itu mendekati derajat Rasul."

Selanjutnya Mahmud Yunus juga mengutip salah satu Hadis yang masyhur, sabda Rasulullah SAW.:

$$
\text { العلماء ورثة الانبياء (رواه البخارى).0 }
$$

Ulama adalah pewaris para Nabi. (H.R. Bukhari).

Dari uraian di atas jelaslah bahwa dalam pandangan Mahmud Yunus pendidik (guru) menempati kedudukan yang tinggi dan mulia, bahkan lebih tinggi dari syuhada. Pendidik adalah pewaris Nabi, pembawa cahaya penerang dalam menuntun peserta didik ke jalan yang lurus, akhlak yang mulia dan keselamatan dunia dan ahirat. Setelah

48 Juwariyah, "Perbandingan Pendidikan Islam Perspektif Mahmud Yunus dan Muhammad ‘Athiyah al-Abrasyi,” Jurnal Pendidikan Islam: Volume IV, Nomor 1, Juni 2015/1436, h. 199

${ }^{49}$ Ibid., h. 59-60

${ }^{50}$ Lihat Imam Bukhari, Shahīh al-Bukhari, (Beirut: Dar al-Kutub al-Ilmiyah, tt), juz. I, h. 26. Redaksi hadis yang lebih lengkap ditemukan dalam Sunan Ibnu Majah: "Sesungguhnya ulama/alim adalah pewaris para Nabi. Sesungguhnya para Nabi tidak mewariskan harta benda (dinar dan dirham), tetapi warisan yang paling berharga dari para Nabi adalah ilmu pengetahuan." (H.R. Ibnu Majah). Imam Ibnu Majah, Sunan Ibn Mājah, (Beirut: Dar al-Fikr, tt.), Juz. I, h. 81 
berakhirnya masa kenabian maka para ulama (pendidiklah) yang akan meneruskan misi dan risalah para nabi.

Masalah akhlak dan etika pendidik mendapat perhatian yang sangat serius dari Mahmud Yunus. Dalam masalah ini Mahmud Yunus mengemukakan rumusan yang sangat panjang dan lengkap sebagaimana termuat dalam bukunya Pokok-pokok Pendidikan dan Pengajaran. Agaknya tepat apa yang dikatakan Ramayulis, ${ }^{51}$ bahwa pemikiran Mahmud Yunus dalam bidang pendidikan sangat memperioritaskan tentang pembentukan akhlak, baik akhlak pendidik maupun akhlak peserta didik.

Akhlak dan etika yang harus dimiliki pendidik menurut Mahmud Yunus sebagai berikut:

Pertama, guru harus mengasihi dan menyayangi murid-muridnya seperti mengasihi dan menyayangi anaknya sendiri, memikirkan keadaan mereka seperti memikirkan keadaan anak-anaknya sendiri. Dalam pandangan Mahmud Yunus seorang guru yang mampu mencurahkan segenap kasih sayang dan perhatian kepada anak didik adalah bapak dan ibu guru yang suci murni. ${ }^{52}$ Beliau mengutip hadis Rasulullah, SAW. yang artinya: "Tidaklah beriman salah seorang di antara kamu, kecuali jika ia mampu mengasihi saudaranya seperti mengasihi diri sendiri." Mahmud Yunus juga mengutip hadis. Sabda Rasulullah SAW.:

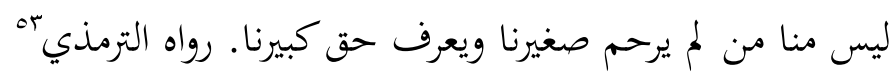

Tidaklah termasuk golongan kami, orang-orang yang tidak mengasihi anak kecil di antara kami dan tidak mengetahui hak orang besar di antara kami.(HR. Tirmizi)

Guru yang cerdas dan memiliki kemampuan menguasai mata pelajaran dan menguasai ilmu pendidikan tidak akan sukses dalam profesinya, sebelum ia mengasihi anak didik dengan sepenuh hati, serta menolong mereka dari kesulitan dalam belajar. Mahmud Yunus mencontohkan bahwa sebuah rumah tangga tidak akan sempurna, kecuali kedua orang tua mampu mencurahkan kasih dan sayang kepada putra putrinya. Selanjutnya Mahmud Yunus memberikan prioritas bahwa anak-anak didik yang harus mendapat perhatian lebih adalah anak didik yang berasal dari keluarga kurang mampu,

51 Ramayulis dan Syamsul Nizar, Ensiklopedi Tokoh Pendidikan Islam: Mengenal Tokoh Pendidikan Islam di Dunia Islam dan Indonesia, (Jakarta: Quantum Teaching, 2010), edisi revisi, h. 326

${ }^{52}$ Mahmud Yunus, Pokok-pokok ..., h. 61-62

${ }^{53}$ Imam al-Tirmidzi, Sunan al-Tirmidzi, hadis no. 1.838 
berakhlak kurang bagus, berhati keras, dan tidak mengenal aturan sama sekali. ${ }^{54}$ Menurut Mahmud Yunus di sinilah kesempatan emas bagi guru, untuk membangkitkan semangat mereka yang telah padam dan menghidupkan jiwa mereka yang telah mati. Salah satu jalan untuk menghidupkan jiwa mereka pendidik harus mengetahui kejiwaan anak dan kecenderungan batinnya, serta berusaha menolong dengan penuh kasih sayang. Dalam hal ini Mahmud Yunus mencontohkan, seorang ahli didik yang profesional di zamannya yakni Pestalozzie. Pestalozzie pernah mengumpulkan 80 orang anak-anak gelandangan, pengemis, dan anak jalanan, kemudian anak-anak tersebut dididiknya dengan penuh kasih sayang dan persaudaraan, bukan dengan ancaman dan hukuman serta menakut-nakuti mereka. Hasil dari proses pendidikan yang dilakukan Pestalozzie menjadikan anak-anak tersebut orang yang cerdas dan kreatif.

Pandangan Mahmud Yunus sejalan dengan pemikiran al-Mawardi, al-Mawardi juga menekankan pentingnya seorang pendidik bersikap lemah lembut dan kasih sayang (al-rifq bi al-muta'allim). Menurut al-Mawardi sikap lemah lembut dan menghargai keterbatasan dan kekurangan mereka sangat penting untuk mendorong mereka agar lebih tekun menuntut ilmu untuk mencapai kemajuan. Sikap lemah lembut dan penyayang ini tercermin pada sikap sopan, ramah, berwajah ceria, bertutur kata yang lembut. Sikap lemah lembut yang dimaksud al-Mawardi adalah sikap lemah lembut dalam batas-batas yang wajar dan pada tempatnya sebagaimana diajarkan Nabi Muhammad SAW. dalam hadisnya: "penduduk surga adalah semua orangnya lembut, sopan dan berwajah ceria." Al-Mawardi menguatkan pendapatnya dengan mengutip bait syair "terkadang saya bersikap lembut dan tegas karena kelembutan tanpa ketegasan adalah tidak baik."

Prinsip yang terkandung dalam pandangan al-Mawardi dalam konteks ini yaitu peran pendidik sebagai orang tua ke dua di sekolah. Pendidik hendaknya memperlakukan peserta didiknya sebagaimana ia memperlakukan anaknya di rumah. Sikap kasih sayang bagi pendidik sangat penting terutama bagi peserta didik di lembaga pendidikan tingkat dasar karena secara psikologis mereka sedang dalam fase

54 Dalam pandangan Mahmud Yunus anak-anak seperti ini sangat banyak dijumpai, dia menggambarkan keadaan mereka: datang dari rumah gubuk, bajunya kotor, kelakuannya buruk, perkataannya kasar, mukanya masam, hatinya keras seperti batu, tiada mengasihi seorangpun, tidak mengenal aturan.

${ }^{55}$ Al-Mawardi, Adāb al-Dunyā wa al-Dīn, (Kairo: Dar al-Fikr, tt.), h. 80 
pertumbuhan yang sangat membutuhkan bimbingan dan kasih sayang dari siapapun juga.

Sikap lemah lembut dan kasih sayang, sangat sesuai dengan psikologi manusia. Diketahui bahwa kegairahan dan semangat belajar seorang peserta didik atau sebaliknya sangat bergantung kepada adanya hubungan antara peserta didik dan pendidik. Apabila pendidik bersikap kasar dan berkeras hati serta menggunakan caracara mengajar yang tidak tepat seperti mengancam, menghina, mengeluarkan perkataan kasar, dan tindakan tidak mendidik lainnya maka niscaya anak didik akan lari dari dirinya. Firman Allah SWT.:

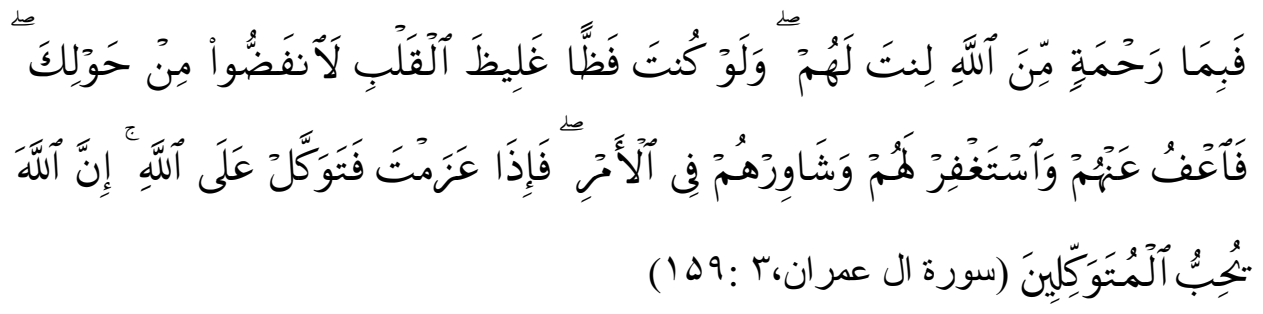

Maka disebabkan rahmat dari Allah-lah kamu berlaku lemah lembut terhadap mereka. Sekiranya kamu bersikap keras lagi berhati kasar, tentulah mereka menjauhkan diri dari sekelilingmu. karena itu ma'afkanlah mereka, mohonkanlah ampun bagi mereka, dan bermusyawarahlah dengan mereka dalam urusan itu. kemudian apabila kamu telah membulatkan tekad, maka bertawakkallah kepada Allah. Sesungguhnya Allah menyukai orang-orang yang bertawakkal kepadaNya. (Q.S. Ali Imran, 3:159).

Dalam hal ini Zakiah Daradjat ${ }^{56}$ mengatakan bahwa pendidik yang keras dan pemarah akan membuat peserta didik menjadi takut dan tertekan mentalnya. Dari perasaan ini akan muncul dan tumbuh sikap benci. Ketakutan akan menimbulkan ketegangan dalam jiwa anak, jika ia selalu tertekan dan mengalami penderitaan batin oleh gurunya, maka pendidik tersebut akan dijauhinya. Secara psikologis, setiap manusia lebih suka diperlakukan dengan cara-cara yang lembut dan halus daripada diperlakukan dengan cara-cara yang kasar dan keras.

Pentingnya sikap lemah lembut dan kasih sayang sebagaimana yang dikatakan Mahmud Yunus, agaknya dapat difahami karena pendidik dalam hal ini memegang peranan strategis dalam menyiapkan bekal dan membimbing peserta didik untuk berhasil dalam kehidupan dunia dan memperoleh kebahagiaan di akhirat.

${ }^{56}$ Zakiah Daradjat, Keperibadian Guru, (Jakarta: Bulan Bintang, 1978), cet. ke 1, h. 14 
Sikap penyayang yang harus dimiliki seorang pendidik yang dikemukakan oleh Mahmud Yunus sejalan juga dengan pandangan al-Qabisi ${ }^{57}$ yang mengungkapkan bahwa pendidik adalah orang tua kedua di sekolah terutama pada anak-anak pada jenjang pendidikan dasar, pengaruh pendidikan tersebut bahkan lebih besar dari pendidikan di rumah tangga yang dilakukan ayah bundanya. Pendapat yang sama juga didukung oleh al-Ghazali yang mengemukakan bahwa pendidik wajib memperlakukan peserta didiknya dengan lemah lembut dan kasih sayang, dan membangkitkan semangatnya untuk mempelajari ilmu yang bermanfaat sebagai bekal meraih kehidupan dunia dan akhirat. ${ }^{58}$ Sejalan dengan pendapat Mahmud Yunus, Muhammad Nawawi ${ }^{59}$ juga mengungkapkan bahwa seorang pendidik harus bersifat lemah lembut dalam menghadapi peserta didik yang tingkat intelektualnya masih rendah, serta membinanya secara sabar sampai kepada tingkat maksimal.

Kedua, guru menjaga hubungan baik dengan anak-anak didik. Dalam pandangan Mahmud Yunus hubungan yang dibangun oleh pendidik bukan saja terbatas pada hubungan fisik namun lebih ditekankan adanya kedekatan batin. ${ }^{60}$ Hubungan batin ini dijalin seperti pendidik menjalinnya dengan anak kandungnya di rumah. Mahmud Yunus mengutip hadis Nabi Muhammad SAW.: Artinya : “Aku dengan kamu seperti ayah dengan anaknya, yakni perhubunganku dengan kamu seperti perhubungan ayah dengan anak-anaknya."

Pendidik tidak dibenarkan memberikan hukuman dengan kekerasan dan memukul peserta didik. Pendidik harus membuang pandangan bahwa memberikan perhatian lebih kepada anak didik dapat mengurangi kehormatan dan popularitasnya,

${ }^{57}$ Al-Qabisi adalah seorang tokoh ulama ahli hadis seorang pendidik yang termasyhur, yang hidup pada 324-403 H di kota Qaerawan, Tunisia. Nama lengkapnya Abu Hasan Ali bin Muhammad bin Khalaf al-Qabisi, lahir pada bulan Rajab 324 H/ 13 Mei 1936 M dan meninggal dunia pada tanggal 3 Rabiul Awal 403 H/ 23Oktober 1012 M. Dia pernah tinggal di Mesir dan berguru pada salah seorang ulama di Iskandariyah. Dia memperdalam ilmu agama, dan al-Hadis dari ulama-ulama terkenal di Afrika Utara, seperti Abul AbbasAl-Ibyani dan Abul Hasan bin Masrur Ad-Dibaghi, dan Abu Abdillah bin Masrur al-Assali, serta ulama terkemuka lainnya. Al-Qabisi adalah ulama hadis yang terkemuka, mengetahui matan-matan dan sanad-sanad al-hadis sehingga dikenal sebagai ulama yang saleh, taqwa, dan wira'i. Ia mengintegrasikan antara ilmu dan ibadah, yang takut kepada Allah, berbudi halus, bersih jiwanya dan pecinta orang fakir, berhati halus dan senantiasa menegakkan qiyam al-lail. Lihat: Ali alJumbulati: Perbandingan Pendidikan Islam, Jakarta: Rineka Cipta, 2002), cet. 2, h. 76-77

${ }^{58}$ Imam Al-Ghazali, Ihyā' 'Ulūm al-Dīn, (Beirut: Dar al-Ma'arif, tt.), Juz I, h. 97

59 Muhammad Nawawi al-Jawi al-Bantani, Muraqqi al-Ubudiyah fi Syarkh al-Bidayah alHidayah, (Bandung: al-Ma'arif, tt.), h. 88

${ }^{60}$ Mahmud Yunus,op.cit., h. 63 
malah sebaliknya guru yang mampu menjalin hubungan batin dengan anak didiknya akan dikenang sepanjang hayat.

Ketiga, pendidik harus memperhatikan kondisi kejiwaan anak didik. Dalam hal ini Mahmud Yunus mengkritisi anggapan masyarakat waktu itu yang memberikan justifikasi bahwa anak-anak yang melakukan tindakan kejahatan adalah karena sifat bawaan sejak lahir dan itu harus diberantas dan diberi hukuman dengan pukulan rotan dan tongkat. Pandangan yang demikian menurut Mahmud Yunus sama dengan mengorbankan masa depan peserta didik dan kelak akan menjadikannya sebagai manusia yang tidak berharga atau tersisih di tengah masyarakat. ${ }^{61}$ Mahmud Yunus mengutip hadis Rasulullah SAW.

كل مولود يولد على الفطرة فابواه يهودانه او ينصرانه او يمجسا نه (رواه البخارى)

Setiap anak dilahirkan dalam keadaan fitrah. Maka kedua orang tuanya

lah menjadikan anak tersebut beragama Yahudi, Nasrani atau Majusi.

(H.R. Bukhari)

Lebih lanjut Mahmud Yunus menjelaskan jika sekiranya anak-anak mendapat didikan yang baik, dalam lingkungan yang baik, dengan perlakuan yang baik dan perhubungan antara guru dan murid, antara ayah dengan anak berjalan secara harmonis niscaya akan berubahlah anak itu dari akhlak yang tercela menjadi akhlak yang terpuji. Dalam bahasa Mahmud Yunus kanak-kanak itu terdiri dari daging, tulang dan darah mempunyai perasaan dan kesadaran, mempunyai tubuh yang harus dilatih, mempunyai akal yang harus dididik, mempunyai hati yang memiliki perasaan sayang atau benci. Mereka akan sayang kepada orang yang sayang kepada mereka. Mereka akan benci kepada orang yang membenci mereka, mereka akan percaya kepada orang yang percaya, dan curiga kepada orang yang mencurigai mereka. Begitulah sifat dasar kanakkanak. Oleh sebab itu mempelajari jiwa dan psikis anak-anak sangat dipentingkan, seorang pendidik yang tidak menguasai jiwa anak-anak ibarat berjalan di dalam gelap gulita. Sejalan dengan pendapat Mahmud Yunus di atas, Ramayulis ${ }^{63}$ juga menekankan pentingnya seorang pendidik mempelajari ilmu jiwa anak-anak. Karena pada masa anak-anak ini menurutnya terjadi perkembangan nilai-nilai keagamaan yang harus

\footnotetext{
${ }^{61}$ Ibid., h. 64

${ }^{62}$ Imam al-Bukhari, Shâhih al-Bukhari, hadis no. 1.358

${ }^{63}$ Ramayulis, Metodologi Pendidikan Agama Islam, (Jakarta: Kalam Mulia, 2008), cet. ke 8, h. $80-81$
} 
difahami oleh seorang pendidik. Ramayulis mengutip pendapat Ernes Harmar bahwa ada 3 fase perkembangan agama pada anak-anak. Pertama, the fairy tale stage (tingkat dongeng). Tingkatan ini dimulai pada anak yang berusia 3 tahun sampai 6 tahun. Pada tingkatan ini konsep mengenai tuhan lebih banyak dipengaruhi oleh fantasi dan emosi. Kedua, the realistic stage (tingkat kenyataan), ini dimulai sejak anak masuk sekolah dasar hingga masuk usia adolesense. Pada masa ini ide ke Tuhanan anak sudah mencerminkan konsep-konsep yang berdasarkan pada kenyataan (realis). Pada masa ini ide keagamaan pada anak didasarkan atas emosional. Ketiga,The Individual Stage (tingkat individu), pada tingkatan ini anak telah memiliki kepekaan emosi yang paling tinggi sejalan dengan perkembangan usia mereka. Demikian juga dengan Syamsu Yusuf, ${ }^{64}$ berpendapat dengan mempelajari ilmu jiwa anak didik maka seorang pendidik akan memahami bahwa pada usia tersebut setiap anak mulai menyadari bahwa pengungkapan emosi secara kasar sangat tidak mereka senangi. Kemampuan mengontrol emosi diperoleh anak melalui peniruan dan pembiasaan. Dalam proses peniruan, maka kemampuan lingkungan anak tinggal sangat mempengaruhi. Apabila anak dikembangkan dalam lingkungan keluarga yang suasana emosionalnya stabil, maka perkembangan emosi anak cenderung stabil. Akan tetapi, apabila kebiasaan keluarga dalam mengekspresikan emosinya kurang stabil dan tidak terkontrol (seperti, melampiaskan kemarahan dengan agresif, mudah mengeluh, kecewa atau pesimis dalam menghadapi masalah), maka perkembangan emosi anak cenderung kurang stabil. Emosi merupakan faktor dominan yang mempengaruhi tingkah laku individu, dalam hal ini termasuk tingkah laku dalam pembelajaran. Emosi yang positif, seperti perasaan senang, bergairah, bersemangat atau rasa ingin tahu akan mempengaruhi individu untuk mengkosentrasikan dirinya terhadap aktivitas belajar, seperti memperhatikan penjelasan guru, membaca buku, aktif dalam berdiskusi, mengerjakan tugas, dan siplin dalam belajar. Sebaliknya apabila yang menyertai proses itu emosi negatif, seperti perasaan tidak senang, kecewa, tidak bergairah, maka proses belajar akan mengalami hambatan, dalam arti individu tidak dapat memusatkan perhatiannya untuk belajar sehingga kemungkinan besar dia akan mengalami kesulitan dan kegagalan dalam belajarnya. Mengingat hal tersebut, maka guru semestinya mempunyai kepedulian untuk menciptakan situasi belajar yang menyenangkan bagi terciptanya pembelajaran

${ }^{64}$ Syamsu Yusuf, Psikologi Perkembangan Anak dan Remaja, (Bandung: Rosda Karya, 2008), Cet. ke 8 , h.181-182 
yang efektif. Upaya aktif yang dapat dilakukan, antara lain: (1) mengembangkan iklim kelas yang bebas dari ketegangan; (2) memperlakukan peserta didik sebagai individu yang mempunyai harga diri (seperti tidak mencemooh, menghina, memaki); (3) memberikan nilai secara objektif; dan (4) menghargai karya peserta didik. ${ }^{65}$

Keempat, guru haruslah sadar akan kewajibannya terhadap masyarakat. Mahmud Yunus berpendapat bahwa guru harus menyadari sepenuh hati bahwa seluruh ilmu yang ajarkan adalah untuk kepentingan masyarakat. Guru mesti menanamkan akhlak yang mulia dan cinta tanah air ke dalam jiwa peserta didiknya. Hanya dengan usaha yang demikian guru dapat membentuk generasi baru dan umat yang sempurna dalam segala segi yang dibutuhkan masyarakat. Guru mesti memperhatikan materi-materi pembelajaran yang diberikan haruslah memberi manfaat dan berguna bagi masyarakat.

Jika dianalisis secara cermat terhadap pandangan Mahmud Yunus tentang akhlak dan etika pendidik ini dapat dikatakan bahwa Mahmud Yunus sangat memperioritaskan tentang pembentukan akhlak, baik akhlak pendidik maupun akhlak peserta didik. Hasil akhir pendidikan harus mampu menjadikan pendidik dan peserta didik yang berakhlak mulia.

\section{Simpulan}

Sebagai seorang pendidik dan pemikir yang memiliki kapasitas pendidikan dan keilmuan yang memadai, Mahmud Yunus memiliki beberapa pemikiran tentang pendidikan Islam sebagai berikut:

Pertama, tujuan pendidikan Islam adalah mendorong seseorang agar mengamalkan ajaran Islam secara sempurna (kaffah), yaitu ajaran yang menyeluruh, artinya peserta didik tidak hanya menguasai ilmu ukhrawi namun juga ilmu duniawi secara berimbang dan dihiasi dengan akhlak mulia, sehingga tercapai kebahagiaan hidup dunia dan akhirat.

Kedua, kurikulum pendidikan merupakan unsur penting dan tidak bisa terpisahkan dalam proses pembelajaran, juga tidak dipisahkan antara mata pelajaran umum dan mata pelajaran agama (integrated).

Ketiga, tentang kelembagaan, Mahmud Yunus termasuk orang yang mempelopori perlunya merubah sistem pengajaran dari yang bercorak individual kepada

\footnotetext{
${ }^{65}$ Ibid.
} 
sistem pengajaran klasikal. Guru mesti mengawasi dan membimbing muridnya dan mengarahkan potensi mereka secara maksimal, dengan penuh kesabaran.

Keempat, metode pembelajaran merupakan hal yang sangat penting dan menentukan dalam pemberhasilan pembelajaran. Dan cara yang paling tepat menurutnya penggunaan metode disesuaikan dengan psikologis peserta didik, kecendrungan, potensi, gharizah, kemampuan dan bakat peserta didik.

Kelima, tentang akhlak dan etika pendidik ini diperioritaskan pembentukan akhlak, baik akhlak pendidik maupun akhlak peserta didik. Hasil akhir pendidikan harus mampu menjadikan pendidik dan peserta didik yang berakhlak mulia.

\section{E. Daftar Kepustakaan}

Ali al-Jumbulati: Perbandingan Pendidikan Islam, Jakarta: Rineka Cipta, 2002, Cet. ke2

Al-Mawardi, Adāb al-Dunyā wa al-Dīn, Kairo: Dar al-Fikr, tt.

Didin Syafruddin, "Mahmud Yunus wa Ijtihatuhu fi Tajdid Ta'lim al-Lughah alArabiyah," Studia Islamika, Vol. 2, No. 3, 1995

Eficandra Masril, Mohd. Nasiran Mohamad, Muhammad Adib Samsudin, Anwar Fakhri Omar, "Pemikiran Fiqh Mahmud Yunus (Fiqh Thought of Mahmud Yunus)," Islamiyat 35 (1), 2013

Fazlur Rahman, Islam, (terj), Bandung: Pustaka, 1984

Harun Nasution dkk., Ensiklopedi Islam Indonesia, Jakarta: Penerbit Djambatan, 1992

Howard Federspiel, Kajian al-Qur'an di Indonesia, Terj. Tajul Arifin, Bandung: Mizan, 1996

Imam al-Bukhari, Shâhih al-Bukhari, hadis no. 1.358

Imam Al-Ghazali, Ihyā' 'Ulūm al-Dīn, Beirut: Dar al-Ma'arif, tt., Juz I

Imam al-Tirmidzi, Sunan al-Tirmidzi, hadis no. 1.838

Imam Ibnu Majah, Sunan Ibn Mājah, Beirut: Dar al-Fikr, tt., Juz. I

Juwariyah, "Perbandingan Pendidikan Islam Perspektif Mahmud Yunus dan Muhammad 'Athiyah al-Abrasyi," Jurnal Pendidikan Islam: Volume IV, Nomor 1, Juni 2015/1436

M. Anwar Syarifuddin, dan Jauhar Azizy, "Mahmud Yunus: Pelopor Pola Baru Penulisan Tafsir al-Qurān Indonesia," Ilmu Ushuluddin, Volume 2, Nomor 3, Januari-Juni 2015

Mahmud Yunus dan Kasin Bakri, al-Tarbiyah wa al-Ta'lim, Jilid 1 a, Gontor: Pondok Pesantren Darussalam Gontor, 1986 
Mahmud Yunus, Metodik Khusus Pendidikan Agama, Jakarta: Hidakarya Agung, 1980, Cet. ke-10

, Metodik Khusus Pendidikan Agama; Metode Mengajarkan Pendidikan Agama di Sekolah Dasar, SMP, SMA, dan Fakultas Umum, Serta Metode Mengajarkan Ilmu Agama di PGAN 6 Tahun, Jakarta: PT. Hidakarya Agung, 1980, Cet. Ke-10

, Pokok-pokok Pendidikan dan Pengajaran, Jakarta: PT. Hidakarya Agung, 1978, Cet. ke-2

--------, Riwayat Hidup Prof. Dr. H. Mahmud Yunus, Jakarta: Hidakarya Agung, 1982

--------, Sejarah Pendidikan Islam di Indonesia, Jakarta: Mutiara, 1979, Cet. ke-2

---------, Akhlak Menurut Al-Qur'an dan Hadis Nabi SAW. Jakarta: Hidakarya Agung, $1978 \mathrm{M} / 1398 \mathrm{H}$

--------, Marilah Sembahyang. Jakarta: Hidakarya Agung, 1979 M/ 1399 H

--------, Keimanan dan Akhlak. Jakarta: Hidakarya Agung, 1979 M/ 1399 H

--------, Pelajaran Agama di Sekolah Lanjutan Pertama. Jakarta: CV. Al-Hidayah, $1977 \mathrm{M} / 1397 \mathrm{H}$

Manfred Oepen dan Walfgang Karcher (ed.), The Impact of Pesantren in Education and Community Development in Indonesia, Jakarta: P3M, 1998

Muhammad Nawawi al-Jawi al-Bantani, Muraqqi al-Ubudiyah fi Syarkh al-Bidayah alHidayah, Bandung: al-Ma'arif, tt.

Ramayulis dan Syamsul Nizar, Ensiklopedi Tokoh Pendidikan Islam: Mengenal Tokoh Pendidikan Islam di Dunia Islam dan Indonesia, Jakarta: Quantum Teaching, 2010, Edisi Revisi

Ramayulis, Ilmu Pendidikan Islam, Jakarta: Kalam Mulia, 2008, Cet. ke-6

--------, Metodologi Pendidikan Agama Islam, Jakarta: Kalam Mulia, 2008, Cet. ke-8

Syamsu Yusuf, Psikologi Perkembangan Anak dan Remaja, Bandung: Rosda Karya, 2008, Cet. ke-8

Syamsul Nizar, Sejarah Pendidikan Islam; Menelusuri Jejak Sejarah Pendidikan Era Rasulullah Sampai Indonesia, Jakarta: Prenada Media Group, 2007

Zakiah Daradjat, Keperibadian Guru, Jakarta: Bulan Bintang, 1978, Cet. ke-1

Zuhairini, Sejarah Pendidikan Islam, Jakarta: Bumi Aksara, 2008, Cet. ke-9 